\title{
Kegiatan Taman Pemulihan Gizi (TPG) terhadap Peningkatan Status Gizi Balita
}

\author{
Mamik Ratnawati ${ }^{1}$, Rini Hayu Lestari ${ }^{2}$, Septi Fitrah Ningtyas ${ }^{2}$ \\ ${ }^{1}$ Program Studi D-III Keperawatan STIKES Pemkab Jombang \\ ${ }^{2}$ Program Studi D-III Kebidanan STIKES Pemkab Jombang \\ Email: mamik.perawat@gmail.com
}

Received 24 August 2018; Accepted 25 August 2018; Published 6 November 2018

\begin{abstract}
The nutritional status of children is one indicator that describes the level of nutritional status of the community. Malnutrition problem is one of the problems that often become controversy in the territory of Indonesia. The purpose of this study is to analyze the Nutrition Recovery Park program to improve the nutritional status of children in Tembelang sub-district, Jombang district. The type of research used is observational analytic research with comparative research design. The sample in this research is children less nutrition and uncomplicated malnutrition in Jatiwates village and Sentul village, Tembelang sub-district, Jombang regency with 11 toddlers. The sampling technique used in this study is total sampling. The dependent variable in this research is the nutritional status of children. The independent variable in this research is Nutrition Recovery Park activity. Data analysis in this research use t-test. The results showed that there is influence of Nutrition Recovery Park activities with nutritional status of children. To further optimize the activities should equip Alat Permainan Edukatif (APE) facilities in order to improve the development of toddlers.
\end{abstract}

Keywords: Nutrition Recovey Park, nutritional status of toddlers

Copyright $\odot 2018$ STIKes Surya Mitra Husada

All right reserved.

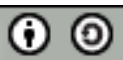

This is an open-acces article distributed under the terms of the Creative Commons AttributionShareAlike 4.0 International License.

\section{PENDAHULUAN}

Zat gizi adalah komponen yang sangat penting yang dibutuhkan oleh tubuh, teurtama pada usia balita karena pada usia balita pertumbuhan sel-sel otak berkembang dengan pesat. Zat gizi pada usia balita harus sangat diperhatikan karena pertumbuhan dan perkembangan saat ini menentukan keadaannya pada saat tumbuh dewasa. Karena sel otak menjadi pondasi utama kecerdasan setiap balita. Sebenarnya pertumbuhan sel otak itu sudah dimulai sejak berada di alam rahim sampai usia 2 tahun setelah lahir, dan akan semakin melambat saat usia 3-4 tahun.

Status gizi balita merupakan salah satu indikator yang menggambarkan tingkat status gizi masyarakat. Salah satu cara penilaian status gizi balita adalah dengan pengukuran antopometri yang menggunakan Indeks Massa Tubuh (IMT) yaitu pengukuran tubuh dibandingkan umur, antara lain Berat Badan menurut Umur (BB/U), Berat Badan menurut Tinggi Badan, atau Tinggi Badan menurut Umur (TB/U) (Kementerian Kesehatan RI, 2013). Jumlah balita di Kabupaten Jombang pada tahun 2014 sebesar 102.578 balita sedangkan yang ditimbang 77.223 balita. Dari hasil penimbangan diketahui balita yang BGM 372 balita $(0,48 \%)$. Sedangkan jumlah balita yang gizi 
kurang 4.160 balita $(6,54 \%)$ dan gizi buruk $372(0,53 \%)$. Keadaan ini menunjukkan perkembangan yang bagus dimana jumlah balita BGM menurun dibandingkan dengan tahun 2013 yaitu balita BGM sebesar 462 balita (0,57\%), Balita Gizi Kurang 3791 balita (5,7\%), Balita Gizi Buruk 462 balita (0,69\%). (Seksi gizi dinkes Kabupaten. Jombang 2014).

Masalah gizi buruk merupakan salah satu masalah yang sering menjadi kontroversi di wilayah Negara Indonesia ini. Menurut Kementerian Kesehatan RI, 2013, jumlah bayi dibawah usia lima tahun yang mengalami masalah dengan kebutuhan gizi meningkat dari angka 17,9\% tahun 2010 menjadi $19,6 \%$. Masalah lain yang berkaitan dengan kebutuhan gizi pada balita adalah adanya stunting di Indonesia. Indonesia menjadi urutan nomer lima di dunia akibat angka pravalensi yang cukup tinggi pada stunting. Stunting adalah ketidaksesuaian antara tinggi badan balita dengan usia yang seharusnya atau bisa dikatakan tinggi badannya lebih rendah. Salah satu contoh lagi permasalahan gizi di Indonesia adalah malnutrisi yaitu gangguan kesehatan yang terjadi karena tubuh tidak dapat mengabsorpsi nutrisi dengan baik atau sebaliknya tubuh tidak mendapatkan nutrisi yang cukup. Seharusnya, tubuh dapat beraktivitas dengan baik jika mendapatkan gizi, nutrisi maupun energi yang seimbang.

Dengan adanya berbagai macam masalah gizi maka diperlukan solusi untuk mengatasi permasalahan tersebut, diantaranya adalah penelitian yang dilakukan oleh De-Regil (2011) menggunakan suplemen zat besi secara intermeitten untuk meningkatkan status gizi pada anak dibawah usia 12 tahun, sedangkan pemerintah Indonesia sendiri sudah melakukan berbagai macam upaya. Salah satunya yang dilakukan pemerintah Kabupaten Jombang pada tahun 2009 untuk mengatasi permasalahan gizi tersebut adalah dengan membentuk Taman Pemulihan Gizi (TPG). Di Taman Pemulihan Gizi para ibu yang memiliki anak usia dibawah lima tahun diberikan pelatihan dan pembinaan mengenai kebutuhan gizi, nutrisi dan energi seorang anak secara optimal. Karena akan berkaitan langsung dengan pertumbuhan dan perkembangan anak. Di dalam Taman Pemulihan Gizi ini juga dilengkapi dengan alat permainan edukatif yang dapat memberikan suasana yang nyaman dan aman bagi balita.

Dari permasalahan tersebut maka diharapkan dari penelitian yang belum pernah dilakukan ini yaitu kegiatan inovasi untuk menanggulangi gizi buruk dan kurang di Kabupaten Jombang berupa pencanangan Penanggulangan Gizi Buruk dengan tema Bertabur Bintang dengan kegiatain Taman Pemulihan Gizi dapat memiliki peranan besar dalam memperbaiki kualitas gizi buruk dan gizi kurang pada balita terutama di wilayah Kabupaten Jombang. Dan dapat memiliki peran secara optimal dalam memajukan program kesehatan yang dibuat oleh pemerintah.

\section{BAHAN DAN METODE}

Jenis penelitian yang digunakan adalah penelitian observasional analitik dengan rancangan penelitian komparatif. Sampel dalam penelitian ini adalah balita gizi kurang dan gizi buruk tanpa komplikasi di desa Gabus Banaran dengan memberikan perlakuan kegiatan Taman Pemulihan Gizi dan desa Sentul tanpa memberikan perlakuan kegiatan Taman Pemulihan Gizi dengan jumlah 11 balita. Teknik sampling yang digunakan dalam penelitian ini adalah total sampling. Variabel terikat dalam penelitian ini adalah status gizi balita. Variabel bebas dalam penelitian ini adalah kegiatan Taman Pemulihan Gizi. Analisis data pada penelitian ini menggunakan $t$-test.

Pengukuran status gizi balita menggunakan Z- skor yang akan dikategorikan: a) Gizi baik, b) Gizi kurang, c) Gizi buruk dan d) Gizi lebih. Status gizi diukur saat kegiatan pada hari pertama kegiatan TPG dan hari ke dua belas kegiatan TPG untuk desa dengan perlakuan. Bagi desa kontrol pengukuran status gizi balita dilakukan dengan waktu yang sama dengan desa perlakuan.

Kegiatan TPG terdiri dari satu periode kegiatan selama tiga bulan dimana tiap-tiap bulan terdapat 12 hari pelaksanaan Hari Makan Anak, yang dilaksanakan satu minggu setelah hari buka Posyandu. Kegiatan dari TPG diantaranya adalah mengumpulkan balita sasaran, penyusunan menu sesuai dengan kesukaan balita di tempat sasaran, pengukuran antropometri (berat badan dan tinggi badan), pemeriksaan medis oleh dokter pada hari pertama, mengolah bahan makanan sesuai jadwal menu oleh ibu balita didampingi kader, permainan dengan APE, dan penyuluhan kesehatan oleh petugas Puskesmas dan kader. 
Sedanglan urutan kegiatan TPG setiap harinya adalah sebagai berikut: a) Sambil menunggu menu diolah dan disajikan, balita bermain dengan APE, b) Cuci tangan dengan sabun dan air mengalir, c) Pembagian makan, d) Berdoa sebelum makan, f) Makan bersama, g) Membersihkan alat makan, h) Pembagian tugas untuk hari berikutnya, i) Pesan kesehatan, dan j) Ibu dan balita pulang.

\section{HASIL}

Tabel 1. Karakteristik ibu balita pada dua desa

\begin{tabular}{lcccc}
\hline \multirow{2}{*}{ Karakteristik sampel } & \multicolumn{2}{c}{ Desa Gabus Banaran } & \multicolumn{2}{c}{ Desa Sentul } \\
\cline { 2 - 5 } & Fekuensi & Prosentase (\%) & Fekuensi & Prosentase (\%) \\
\hline Tingkat Pendidikan: & & & & \\
\hline Tidak sekolah & 0 & & 0 & \\
\hline Dasar & 2 & 9,52 & 2 & 18,18 \\
\hline Menengah & 8 & 80,95 & 8 & 72,73 \\
\hline Tinggi & 1 & 9,52 & 1 & 9,9 \\
\hline Pekerjaan: & & & & \\
\hline$\quad$ Tidak bekerja & 9 & 95,24 & 9 & 81,82 \\
\hline Bekerja & 2 & 4,76 & 2 & 18,18 \\
\hline Tanggungan Keluarga: & & & & \\
\hline Tidak ada & 5 & 23,81 & 6 & 54,55 \\
\hline Ada & 6 & 76,19 & 5 & 45,45 \\
\hline
\end{tabular}

Hampir seluruhnya ibu balita pada desa Sentul dan Gabus Banaran adalah berpendidikan menengah. Hampir seluruhnya ibu balita pada desa Sentul dan Gabus Banaran adalah tidak bekerja. Separo ibu balita pada desa Gabus Banaran dan Sentul tidak terdapat tanggungan keluarga.

Tabel 2. Distribusi Frekuensi Responden Berdasarkan status gizi pre test dan post test di Desa Gabus Banaran Kecamatan Tembelang Pada Bulan September - Nopember 2017

\begin{tabular}{lcccc}
\hline \multirow{2}{*}{ Status gizi } & \multicolumn{2}{c}{ Pre test } & \multicolumn{2}{c}{ Post test } \\
\cline { 2 - 5 } & $\mathrm{f}$ & $\%$ & $\mathrm{f}$ & $\%$ \\
\hline Baik & 0 & 0 & 10 & 90,91 \\
\hline Kurang & 9 & 81,82 & 1 & 9,09 \\
\hline Buruk & 2 & 18,18 & 0 & 0 \\
\hline Jumlah & 11 & 100 & 11 & 100 \\
\hline
\end{tabular}

Berdasarkan tabel 2 menunjukkan bahwa hampir seluruhnya $(81,82 \%)$ responden pre test berstatus gizi kurang, dan sebagian kecil $(18,18 \%)$ responden post test berstatus gizi baik pada desa dengan kegiatan Taman Pemulihan Gizi.

Tabel 3. Distribusi Frekuensi Responden Berdasarkan status gizi pre test dan post test di Desa Sentul Kecamatan Tembelang Pada Bulan September - Nopember 2017

\begin{tabular}{lcccc}
\hline \multirow{2}{*}{ Status gizi } & \multicolumn{2}{c}{ Pre test } & \multicolumn{2}{c}{ Post test } \\
\cline { 2 - 5 } & $\mathrm{f}$ & $\%$ & $\mathrm{f}$ & $\%$ \\
\hline Baik & 0 & 0 & 1 & 9,09 \\
\hline Kurang & 8 & 72,73 & 7 & 63,64 \\
\hline Buruk & 3 & 27,27 & 3 & 18,18 \\
\hline Jumlah & 11 & 100 & 11 & 100 \\
\hline
\end{tabular}


Berdasarkan tabel 3 menunjukkan bahwa hampir seluruhnya (72,73\%) responden pre test berstatus gizi kurang, dan sebagian besar $(63,64 \%)$ responden post test berstatus gizi kurang pada desa tanpa kegiatan Taman Pemulihan Gizi.

Tabel 4. Uji Wilcoxon signed rank test pada status gizi balita pre test post test.

\section{Ranks}

\begin{tabular}{llccc}
\hline & & $\mathrm{N}$ & Mean Rank & Sum of Ranks \\
\hline DesaTanpaTPG - & Negative Ranks & $10^{\mathrm{a}}$ & 5.50 & 55.00 \\
\cline { 2 - 5 } Desa DgnTPG & Positive Ranks & $0^{\mathrm{b}}$ & .00 & .00 \\
\cline { 2 - 5 } & Ties & $1^{\mathrm{c}}$ & & \\
\cline { 2 - 5 } & 11 & & \\
\hline
\end{tabular}

a. Desa Tanpa TPG $<$ Desa DgnTPG

b. Desa Tanpa TPG > Desa DgnTPG

c. Desa Tanpa $T P G=$ Desa DgnTPG

\section{Test Statistics ${ }^{\mathrm{a}}$}

\begin{tabular}{lc}
\hline & DesaTanpaTPG - DesaDgnTPG \\
\hline$Z$ & $-3.162^{\mathrm{b}}$ \\
\hline Asymp. Sig. (2-tailed) & .002 \\
\hline
\end{tabular}

a. Wilcoxon Signed Ranks Test

b. Based on positive ranks.

Berdasarkan metode perhitungan yang dilakukan di dalam rumus Wilcoxon Signed Rank test, nilai-nilai yang didapat adalah nilai mean san sum of rank dari kelompok negarif ranks, positive ranks dan ties.

Negatif rank artinya sampel dengan nilai kelompok kedua (desa tanpa TPG/post test) lebih rendah dari nilai kelompok pertama (desa dengan TPG/pre test).

Positive rank artinya sampel dengan nilai kelompok kedua (desa tanpa TPG/post test) lebih tinggi dari nilai kelompok pertama (desa dengan TPG/pre test).

Sedangkan ties adalah nilai kelompok kedua (desa tanpa TPG/posttest) sama besarnya dengan nilai kelompok pertama (desa dengan TPG/pre test). Simbol N menunjukkan jumlahnya, Mean Rank adalah peringkat rata-ratanya dan sum ranks adalah jumlah dari peringkatnya.

Berdasarkan hasil dari perhitungan Wilcoxon Signed Rank Test, maka nilai Z yang didapat sebesar-besarnya 3,162 dengan p value (Asymp. Sig 2 tailed) sebesar 0,002 dimana kurang dari batas kritis penilitian 0,005 sehingga keputusan hipotesis adalah menerima $\mathrm{H} 1$ atau yang berarti terdapat perbedaan bermakna antara kelompok desa tanpa TPG (pre test) dan desa dengan TPg (post test).

\section{PEMBAHASAN}

Tabel 1 menunjukkan bahwa hampir seluruhnya $(81,82 \%)$ responden pre test berstatus gizi kurang, dan sebagian kecil $(18,18 \%)$ responden post test berstatus gizi baik.

Usia balita adalah periode penting dalam proses tumbuh kembang anak yang merupakan masa pertumbuhan dasar anak dan orang tua terutama ibu adalah orang yang terdekat tempat anak untuk tumbuh kembang (Dewi, 2011). Hal ini sesuai dengan referensi bahwa pertumbuhan merupakan bertambahnya jumlah serta besarnya sel di seluruh bagian tubuh yang secara kuantitatif dapat diukur dengan penimbangan, pengukuran. Berdasarakn buku pedoman tentang Taman Pemulihan Gizi Dinas 
Kesehatan Kabupaten Jombang (2009) bahwa waktu observasi pelaksanaan kegiatan terebut adalah selama tiga bulan untuk mengetahui apakah ada perbaikan status gizi balita terutama status gizi. Adanya beberapa kenaikan ini disebabkan antara lain karena peran serta ibu dalam kegiatan yang ada di desa.

Pertumbuhan pada balita tidak hanya memerlukan sekali intervensi saja tetapi perlu modifikasi atau multi intervensi terutama pada balita denagn masalah gizi. Hal ini dibuktikan oleh penelitian Ramakharisman, et al (2004), dalam penelitiannya menggunakan vitamin A dan zat besi. Pada balita yang diberikan intervensi besi saja atau vitamin A saja tidak meningkatkan status gizi balita.

Jika dilihat kenyataan di lapangan pertumbuhan balita pada kegiatan TPG lengkap dalam menangani masalah gizi sangatlah ketat observasinya sehingga dengan cepat deteksi dini terhadap kenaikan berat badan balita. Ibu balita setiap kegiatan TPG juga diajari bagaimana cara menyajikan menu yang sesuai dengan balita terutama yang berkaitan dengan kandungan gizinya. Selain itu dalam tahun pertama adanya TPG ibu balita ini masih antusias dengan kegiatan TPG karena kegiatan tersebut merupakan satu-satunya solusi untuk mengatasi masalah gizi yang ada di kabupaten Jombang. Hal tersebut juga didukung oleh peran para petugas kesehatan terutama bidan yang ada di tiap desa untuk mempromosikan dan berperan serta di setiap kegiatan TPG.

Penelitian ini menunjukkan bahwa kegiatan TPG lebih efektif dan keberhasilannya cukup tinggi dalam peningkatan status gizi balita. Pada kegiatan TPG sebagian besar mengutamakan untuk peningkatan status gizi. Penelitian yang dilakukan oleh Wahyuningsih tentang kegiatan TPG dengan status gizi didapatkan juga banyak yang mengalami peningkatan, salah satu faktor yang mendukungnya adalah peran serta kader dan bidan dan yang lebih penting lagi adalah motivasi ibu balita itu sendiri.

Penelitian yang dilakukan oleh Novitasari (2012) menyatakan bahwa balita yang menderita gizi buruk akan mengalami penurunan daya tahan sehingga rentan terhadap penyakit. Selain itu anak yang menderita sakit akan memperjelek keadaan gizi melalui gangguan asupan makanan dan meningkatkan kehilangan zat-zat gizi esensial. Penelitian yang dilakukan oleh de Caballero, et al. menggunakan makanan tambahan untuk meningkatkan gizi pada balita pada anak di bawah lima tahun, sedangkan penelitian oleh Kimutai, et al. menggunakan hypo-phosphatemia untuk balita dengan masalah gizi yaitu kwashihorkor dan marasmus - kwashihorkor. Kedua penelitian tersebut menghasilkan balita banyak mengalami perbaikan status gizi.

Pada penelitian ini data yang terpakai sebagai acuan peningkatan status gizi balita adalah data primer. Pada penelitian ini masih menggunakan perbandingan antara tinggi badan dan berat badan. Faktor yang sangat berpengaruh besar adalah pola asuh orang tua dan lingkungan. Pola asuh disini adalah pengetahuan orang tua mengenai nutrisi pada setiap usia, yang mana tiap usia tidak sama dalam hal bentuk atau jumlah makanan yang diberikan. Banyak balita mendapatkan nutrisi tidak sesuai dengan usianya, apalagi jika diasuh oleh nenek atau orang lain. Kebanyakan dari pengasuh balita ini merasa senang jika balitanya diam dengan cara memberikan makanan atau jajanan luar yang pastinya bisa mengganggu pertumbuhan. Hal ini sesuai dengan penelitian Munawaroh (2016) bahwa pola asuh pemberian makanan oleh orang tua mempunyai hubungan yang signifikanterhadap status gizi balita. Semakin baik pola asuh yang diberikan maka semakin baik status gizi balita dan sebaliknya apabila ibu memberikan pola asuh yang kurang baik dalam pemberian makanan pada balita maka status gizi balita juga akan terganggu.

\section{KESIMPULAN}

Berdasarkan pembahasan yang telah dilakukan, dapat disimpulkan sebagai berikut: Ada perbedaan status gizi balita yang mendapat perlakuan kegiatan TPG dengan balita yang tidak mendapat perlakuan kegiatan TPG. 


\section{REFERENSI}

De Caballero, e., Sinisterra, O., Lagrutta, F., \& Atalah, E. (2004). Assessment of the nutritional impact of the complementary feeding program of panama in children under five years old. 54(1):66-71. (abstr).

De-Regil, L. M., Jefferds, M. E., Sylvetsky, A. C., Dowswell, T. (2011). Intermittent iron supplementation for improving nutrition and development in children under 12 years of age.

Dewi, N. A. (2011). Skripsi Faktor Dominan Karakteristik yang Berhubungan dengan Pertumbuhan dan Perkembangan Balita Usia 2 - 5 Tahun di Wilayah Kera Puskesmas Naggalo Kota Padang, Universitas Andalas.

Dinas Kesehatan Kab. Jombang. (2007). Pedoman Pelaksanaan Stimulasi, Deteksi dan Intervensi Dini Tumbuh Kembang Anak Di Tingkat Pelayanan Kesehatan Dasar, Jombang.

Dinas Kesehatan Kab. Jombang. (2014). Profil Dinas Kesehatan kab. Jombang, Jombang. 2014. Profil Dinas Kesehatan kab. Jombang, Jombang.

Kimutai, d., maleche-obimbo, e., kamenwa, r., murila, f. (2009). Hypo-phosphataemia in children under five years with kwashiorkor and marasmic kwashiorkor. 86(7):330-6. (abstr).

Ramakharishnan, U., Abourto, N., Mc Cabe, G., \& Martorell, R. Multimicronutrient Interventions but not Vitamin a or Iron Interventions Alone Improve Child Growth: Results of 3 Meta-analyses, Atlanta: Oktober 2004. J Nutr.134 (10): 2592-602.

Munawaroh, S. (2016). Skripsi Pola Asuh Mempengaruhi Status Gizi Balita, Fakultas Ilmu Kesehatan Universitas Muhammadiyah Ponorogo.

Novitasari, D. (2012). Faktor- faktor Resiko Kejadian Gizi Buruk pada Balita yang Dirawat di RSUP Dr. Kariadi Semarang. Jurnal Media Medika Muda.

Kemenkes Kesehatan Republik Indonesia. (2013). Riset Kesehatan Dasar (Riskesdas). (2013). Diakses: 19 Oktober 2014, dari http://www.depkes.go.id/resources/download/general/Hasil\%20Riskesdas\%20 2013.pdf. 